ZHONGZHEN YANG, Ph.D. ${ }^{1}$

(Corresponding author)

E-mail:yangzz_dl@163.com

CHUNYU GAO, M.S. ${ }^{1}$

E-mail:1430957308@qq.com

YIXUAN LI, M.S. ${ }^{1}$

E-mail:2091366741@qq.com

${ }^{1}$ Transportation Management College

Dalian Maritime University

Dalian, 116026, P.R. China
Transport and Sustainable Development Preliminary Communication Submitted: Apr. 13, 2015 Accepted: Feb. 10, 2016

\title{
OPTIMIZATION OF COASTAL CRUISE LINES IN CHINA
}

\begin{abstract}
The paper analyzes the current state of the Chinese cruise market and presents the idea of building a business model of coastal cruising. The cruise demand of middle-income families, which includes the desired travel days, ports of call, is surveyed. The data of the previous non-cruise travels and the data of future cruises of middle-income families are used to develop a model designed to identify the maximum passenger volume with minimum operating costs while taking cruise itineraries and schedules into account. A matrix coding genetic algorithm was designed to solve the model. The case study found that a voyage of 4.79 days results in equilibrium, that the annual demand is 200,840 passengers, and that the daily voyage cost is 0.843 million Yuan.
\end{abstract}

\section{KEY WORDS}

cruise travel; matrix coding; coastal cruise;

\section{BACKGROUND}

The quickly expanding cruise sector is the fastest growing segment in the tourist industry [1-2]. The cruise market provides many services to satisfy the demands of tourists. Cruise Lines International Association (CLIA) has classified cruises into three types: global cruise lines, regional cruise lines, and coastal cruise lines. The cruise industry is attracting increased attention in China due to the continual increases in personal income.
China has been an international cruise destination since 1978 due to its "reform and open" policy. Before the 1980s, the Chinese cruise industry was wrapped in a shroud of mystery and was believed to be a luxury of the rich. As a steady stream of international cruise liners have visited China since that time, the Chinese cruise industry has entered the reception stage, which means that only some ports are called by the cruises but there is no home port for the cruise traffic. In addition, there has been a rapid increase in the number of international cruise liners calling at Chinese ports. International cruise lines are increasingly paying close attention to the Chinese market.

Table 1 shows the situation of the cruises in China. The data come from annual China cruise industry development report released by China Cruise \& Yacht Industry Association (CCYIA) and Shanghai International Shipping Institute [3-6]. In 2008, the first Asian Cruise Liner Conference was held in Shanghai. At the conference, cruise line magnates gathered and discussed the problems of exploiting this new market. During the same year, approximately 63 international cruises set off from the Chinese homeports. Chinese outbound tourists travelled by cruise ship numbered 110,000, and the total number of international outbound and inbound visitors was 401,000. In 2010, the Royal Caribbean International inaugurated international cruises in China, Japan, and Korea, which began at the home ports of Hong Kong, Shanghai, and Tianjin [6] and Chinese cruise industry kept developing.

Table 1 - Current Situation of the cruises in China

\begin{tabular}{||c|c|c|c||}
\hline Year & $\begin{array}{c}\text { Cruises departed from } \\
\text { Chinese Ports }\end{array}$ & $\begin{array}{c}\text { Chinese Outbound Tourists } \\
\text { by cruise ship }\end{array}$ & $\begin{array}{c}\text { Total International inbound } \\
\text { and outbound visitors }\end{array}$ \\
\hline \hline 2008 & 63 & 110,000 & 401,000 \\
\hline 2009 & 80 & 200,000 & 406,500 \\
\hline 2010 & 95 & 226,000 & 470,000 \\
\hline 2011 & 142 & 252,084 & 504,582 \\
\hline 2012 & 170 & 420,000 & 660,000 \\
\hline
\end{tabular}

Source: Annual China cruise industry development report released by China Cruise \& Yacht Industry Association (CCYIA) and Shanghai International Shipping Institute [3-6] 
Currently, the international cruise companies that operate in China are Costa Cruises, Royal Caribbean International, and Star Cruises. Their routes cover Southeast Asia, Asia, the Middle East, Europe, and America. China has five domestic cruise companies which are controlled by China: the Pacific Cruise Line, the Shenzhen Wanbang Enterprise Group, Hong Kong Sea Princess Luxury Cruises Co. Ltd., North Sea Ming Flower Luxury Cruise Service Co. Ltd., and China Cruise Co. Ltd. These companies primarily focus on the coastal shipping lines in China and South Asia.

The Chinese government also plans to promote cruise tourism. The transport industry's "12th 5-year" national plan proposes that high-speed craft (a high speed water vessel for civilian use), the RoRo ships, and water tourism transport should be vigorously developed. The government will market cruises in Dalian, Tianjin, Qingdao, Xiamen, Shenzhen, and Beihai. In the meantime, cruise homeports will be built at Sanya and Shanghai to extend the industrial chain and improve cruise line services [7]. Currently, many port cities, such as Shanghai, Tianjin, Qingdao, Dalian, Sanya, and Weihai, are making substantial efforts to develop the cruise industry and create the cruise centres.

Some Chinese port cities have made substantial investments in building cruise ports that act as urban landmarks. As shown in Figure 1, five cruise terminals have been built in China: Tianjin International Cruise Terminal, Shanghai North Bund International Cruise Terminal, Shanghai Wusongkou International Cruise Terminal, Xiamen International Cruise Terminal, and Sanya Phoenix Island International Cruise Terminal. Moreover, other three cruise terminals are under construction: Zhoushan Archipelago International Cruise Terminal, Qingdao International Cruise Terminal, and Dalian International Cruise Terminal.

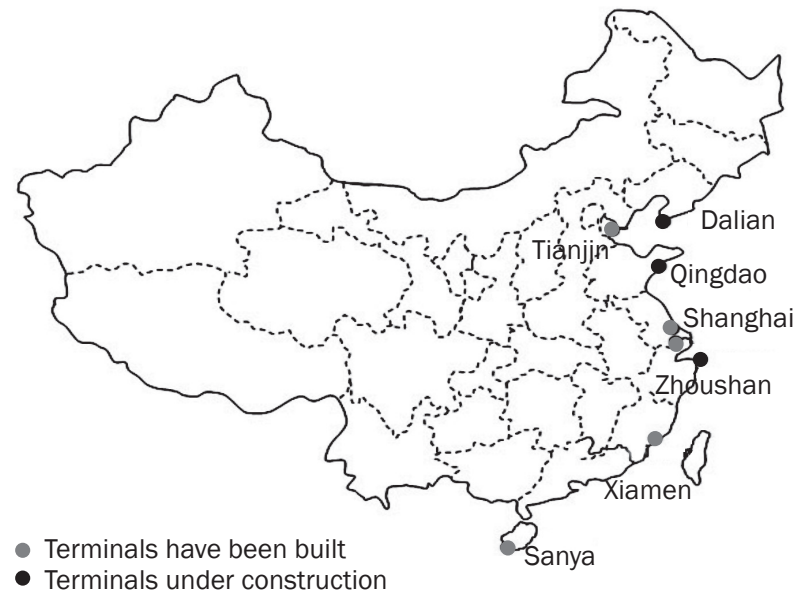

Figure 1 - Location of Chinese cruise ports

However, Chinese cruise products reproduced from the European and American markets that are not completely applicable to the current Chinese market, such as 1) indulging the travel demands of high-end customers and charging prices that are unaffordable to the Chinese middle-income families; 2) overly complicated application procedures involving visas or other formalities, which require tourists to enlist the assistance of travel agencies and consume too much time; and 3) overly Westernized dining and entertainment, to which it is difficult for Chinese customers to become accustomed.

Despite the late start of China's cruise industry, international cruise magnates are confident in its future. However, if market demand for cruise tourism is not effectively guided, this may result in problems such as overcapacity and cutthroat competition. In such a situation, cruise magnates may profit, but Chinese ports or port cities may experience losses. The phenomenon has occurred in other fields in China, such as rare earth export, iron ore import, and the photovoltaic manufacturing business. Therefore, in China, it is vitally important to encourage the development of local cruise enterprises and to design cruise lines rationally in a manner that stimulates the demand of most Chinese tourists.

Coastal cruise tourism is a type of cruise service along the coastline in one country. It operates midsized ships that are equipped with excellent service and facilities and sails relatively short distances, such as between Shanghai and Wenzhou or Shanghai and Putuo Island. However, due to poor product design and market positioning, this sector of the Chinese cruise industry has performed far below expectations.

To promote the development of the Chinese cruise market, coastal cruise tourism should be well designed from the beginning. By offering a unique service that meets domestic demand, the consumption of coastal cruises may be encouraged. This paper analyzes the current state of the Chinese cruise market, explores strategies to develop that market, and designs itineraries for coastal cruise tourism.

The rest of this paper is organized as follows. Section 2 contains a literature review; Section 3 describes the demand survey and its results; Section 4 provides the model structure and solution algorithm; Section 5 demonstrates a numerical example; and Section 6 presents the conclusions.

\section{LITERATURE REVIEW}

The existing literature mainly concentrates on tourists' behaviours, market potential, cruise traffic of a port, changes of the cruise market, cruise fleet deployment, factors for the itineraries, lifestyles, values, and attitudes. To evaluate factors influencing tourists' travel choice, Heung et al. [8] and Qu et al. [9] study the motivation and satisfaction of cruise tourists in Hong Kong and develop a performance model. They systematically survey 330 tourists and find that cruise-related 
consumption behaviours are determined by accommodation, entertainment, and food and beverage service. Teye and Leclere [10] analyze tourists' satisfaction with cruise line service in North America and conclude that tourists' satisfaction exceeds the expectations. Durnana and Mattilab [11] demonstrate the relationship between tourists' emotions and the value of a cruising experience. They find that the emotional factor determines experiential satisfaction.

With respect to cruise tourism products, Klein [12] highlights that cruise companies use cunning tactics in order to maximize on-board sales. He maintains, like Johnson [13], that cruise ships are promoted to an increasing degree as destinations sui generis, rather than as means of transportation or as floating hotels which bring tourists to new and interesting ports of call. Hwang and Han [14] test the hypothesis that the experiential factors of food quality, service quality, staff/crew attractiveness, entertainment, ship facilities, ports of call, children's programs and/or supervision, and cabin quality influence the formation of the brand prestige of cruise services and find that all of their proposed hypotheses are statistically supported. Henthorne [15] studies the length of voyages and finds that 3-, 4- and 7-day cruises are the most popular ones. Generally, the market share of cruises ranging from 2-5 days is steadily increasing, whereas cruises of more than 9 days are decreasing. The most popular voyages are those lasting 6 - 8 days.

With respect to the cruise itineraries, Lee and Ramdeen [16] perform a linear regression analysis of the data and report that cruise itineraries have a significant effect on occupancy rates. Dickinson and Vladimir [17] conclude that itineraries have changed to a loop type, during which tourists no longer travel from $(A)$ to $(B)$ but from $(A)$ to $(B)$ to $(C)$ and then back to (A). Moreover, extensive marketing and exploration of various services to develop different market segments were proposed. Hersh and Ladany [18] present a twostage method: first, to estimate the demand through a regression method that includes voyage days, departure times, daily ticket price, port dwelling time, and ship specification as parameters; second, to build a dynamic programming model to determine an optimal route based on the demand function. Leong and Ladany [19] optimize the cruise route scheme with the goal of maximizing the route attractiveness, including ports of call, port dwelling time, and calling order. Rodrigue and Notteboom [20] argued that the cruise industry sells itineraries, not destinations. Because, the itinerary design are affected by market circumstances and requirements such as the seasonality in demand, the optimal duration of a cruise vacation, the balance between sailing time and shore time, the existence of 'must see' destinations and overall guest satisfaction, thus the cruise operators are challenged to develop competitive cruise packages but at the same time they have to optimize the deployment of their cruise ship fleet in view of minimizing operating costs and/or maximizing revenue per passenger slot. Once the market potential for a new service has been determined, the service planners need to take decisions on several interrelated core design variables.

Cruise tourism began late in China. Since the Caribbean market is saturated, mass-market ships are gradually relocating to China [21]. Thus, studies of the Chinese cruise industry are relatively simple. Most of the existing studies focus on the economic benefits and effects of cruise tourism, the planning of cruise industry for ports or cities, and the construction of new cruise ports. Luo et al. [22] analyzed the cruise development of the West Coast of the Straits Economic Zone centred around Xiamen city by SWOT method. Zhang and Fang [23] used SWOT to analyze the development of Qingdao cruise tourism conditions and forecasted the trend of its development. Sun and Ye [24] analyzed the strengths, weaknesses, opportunities and threats of cruise tourism in Shanghai, and proposed the suggestions of how to develop cruise tourism in Shanghai. Wang and Lou [25] took the Carnival Corporation as an example and studied the spatial distribution of ports of call and cruise routes. By comparing their operating performances, a home port is suggested to be built in Shanghai.

It can be concluded that the existing studies address cruise motivation, tourists' behaviours, tourists' satisfaction, factors of itinerary design, customer demand, industry development, and home-port construction. However, studies address these issues at the macroscopic level. It is difficult to find studies on market demand for coastal cruise tourism or literature on the relationship between travel demand and cruise itineraries, especially the way of converting potential cruisers to cruisers. According to China cruise industry development report, middle-income families are regarded as the main potential cruise tourists in China [3-6]. The majority of previous studies have considered the optimization of route structures. However, Yao et al. [26] focused exclusively on designing route structures and then applied taboo search to determine the optimal route set. More importantly they determine whether the service has sufficient capacity to meet potential passenger demand.

Therefore, it is necessary to study the demand of middle-income families for cruise tourism and to build a model to simulate the dynamic interaction between itinerary and cruise traffic. An equilibrium itinerary scheme and its corresponding cruise traffic can be obtained by calculating the proposed model. 


\section{COASTAL CRUISE TOURISM DEMAND SURVEY}

Travel demand is a key factor in tourism product design. To understand the demand of middle-income families for cruise tourism, we conducted a survey in Dalian, Shenyang, Changchun and Harbin (four large cities in northeast China). According to the Ministry of Finance in China, Chinese urban households (commonly calculated by the family of three) whose annual pre-tax income average 60,000-200,000 yuan are normal middle-income families in China. The relationship between the income level and the categories of occupations in northeast China was investigated, and middle-income group mainly includes civil servants, managers of export-oriented enterprises, university professors, and senior engineers at consulting companies. Therefore, occupations mentioned above are selected as samples and can represent the population of interest in northeast China. The results of the survey found that the annual income of all the samples is between 60,000 and 100,000 . It has been proven that the selected sample can represent the population of interest in northeast China.

Through face-to-face interviews (87\%) and e-mail questionnaires (13\%), 353 valid surveys were collected. The first group of questions asked about the respondents' previous travel experiences, including queries related to travel frequency, cost, and time spent. The second group of questions asked about the respondents' expectation for cruise tourism, including favourable itineraries, voyage days, and the number of ports of call. The third group of questions asked about the respondents' preferences related to on-board activities and services, including expected ship size, entertainment facilities, special services, and associated costs. The final group of questions surveyed the respondents' need for land-based activities during cruise trips, including the preferred length of time spent in each port city, onshore sightseeing spots, and shopping centres.

Summarizing the results of the questionnaire, we found that most of the respondents travel once per year and that their average travel time is $2-5$ days (Figure 2). It can be concluded that the middle-income families in northeast China do not have much leisure time and that short-duration cruises might be most appropriate for them.

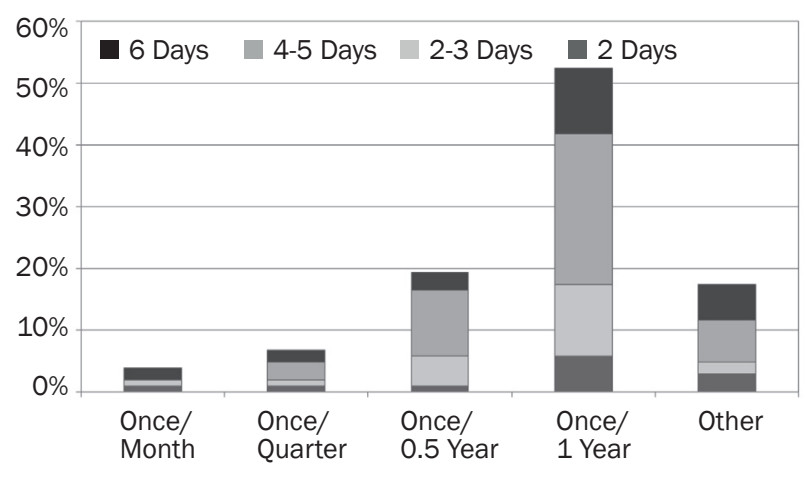

Figure 2 - Travel frequency and travel days

The acceptable price of a coastal cruise line is shown in Figure 3. Considering the price of Yangtze River Cruise and household expenditure on tourism in northeast China, four options are set for this question. For a cruise of 4-5 days, 3,000-5,000 Yuan is the most acceptable price range.

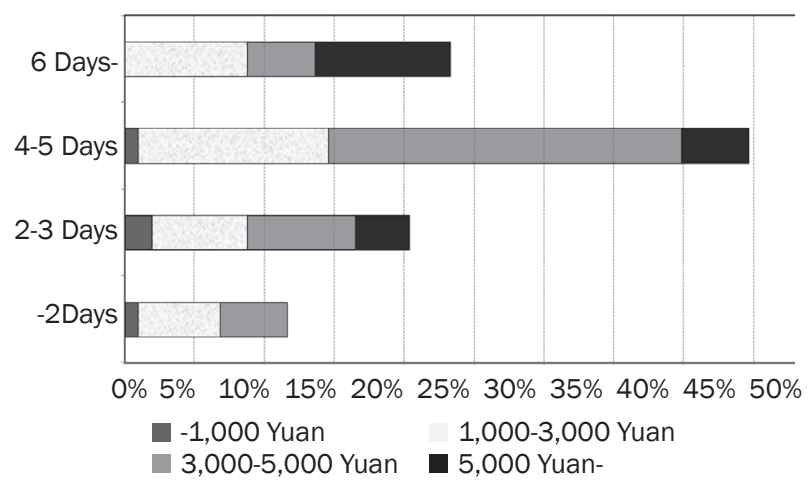

Figure 3 - Combination of costs and travel days

With respect to ports of call, approximately 35\% of the respondents believed that the number of ports of call was unimportant; what mattered were the port cities' tourist attractions. The survey included questions about particular ports and found that $66 \%$ of respondents wanted to visit Qingdao and 62.1\% wanted to visit Shanghai (Figure 4). Moreover, the respondents preferred scenic landscapes and cultural relics. Consistent with the respondents' travel habits, sightseeing spots were deemed attractive features of a cruise.

Based on the above survey, a cruise itinerary optimization model was proposed. In the case study, Dalian was chosen as the home port and middle-income families of northeast China were considered as the potential tourists. 


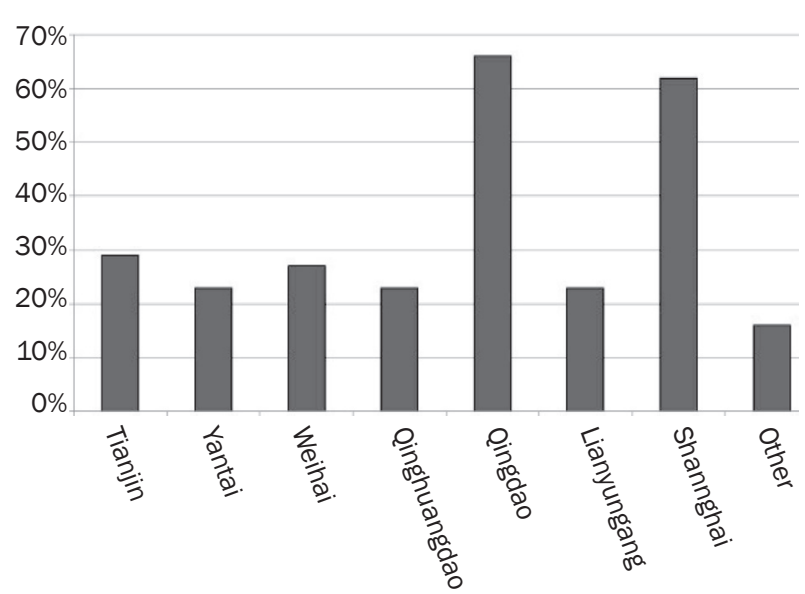

Figure 4 - Preference for various ports of call

\section{ITINERARY OPTIMIZATION MODEL}

Existing shipping-line optimization models generally assume that transport demand is predetermined. However, in practical terms, the number of passengers served by a cruise line is closely related to its itineraries [27-29]. Many customers specifically consider the unique ports of call offered when selecting a cruise package [30-31]. Thus, it is not possible to obtain a practical result merely by minimizing voyage costs. Our model considers minimum daily costs and maximum passenger numbers as dual objectives. Moreover, since the middle-income families are short on leisure time, one important constraint in our model is time, which is expressed as voyage days.

\subsection{Optimization model}

\subsubsection{Model assumptions and variable list}

The model incorporates the following assumptions:

1) The cruise line is a continual one-way loop, passengers can disembark and re-embark at any port of call;

2) The number of potential passengers between the ports is known by forecasting with survey data and social-economic data under sa given cruise fair level;

3) Voyage costs include fuel and port tariffs; the costs of materials and vessel capital costs are not taken into consideration;

4) All ports' tariffs are at the same level;

5) The berthing time at each port of call is 6 hours. The used variables are defined as follows:

Q passenger volume

$n \quad$ number of candidate ports

$L \quad$ set of feasible itinerary schemes

$T \quad$ sailing time

$\begin{array}{ll}\alpha & \text { port tariff } \\ \Delta & \text { passenger boarding speed } \\ Y & \text { boarding fare (charged by time) } \\ F C & \text { daily consumed heavy oil } \\ F C P & \text { price of heavy oil } \\ D C & \text { daily consumed light oil } \\ D C P & \text { price of light oil } \\ C_{P} & \text { port-related costs } \\ C_{S} & \text { sailing costs } \\ N_{C} & \text { number of crew members } \\ C_{W} & \text { daily crew wage } \\ T_{S} & \text { sailing time } \\ T_{P} & \text { time in port } \\ d_{i j} & \text { sailing distance from port } i \text { to port } j \\ Q_{i j}{ }^{0} & \text { potential passenger volume between ports } i, j \\ P_{i} & \text { attraction of port } i \\ T_{d} & \text { expected maximum voyage days } \\ S_{b} & \text { standard ratio between crew members } \\ & \text { and passengers on board }\end{array}$

\subsubsection{Model structure}

The dual-objective cruise itinerary optimization model is as follows:

Min: $Z=f(Q, I)$

$\operatorname{Max}: Q=Q(I)$

$\mathrm{ST}: \sum_{j=1}^{n} x_{1 j}=\sum_{i=1}^{n} x_{i 1}=1$

$\sum_{j=1}^{n} x_{i j}=\sum_{i=1}^{n} x_{j i} \leq 1$

$\sum_{j=1}^{n} x_{i j}+\sum_{i=1}^{n} x_{j i} \leq 1$

$2 \leq T \leq 5$

$\sum_{j=1}^{n}=\sum_{i=1}^{n} x_{i j}>2$

$x_{i j}$ is the decision variable: if the leg from port $i$ to port $j$ is on the cruise itinerary scheme, then $x_{i j}=1$; otherwise, $x_{i j}=0 . n$ is the number of candidate ports. The first objective (Equation 1) is to minimize daily costs, and the second (Equation 2) is to maximize passenger volume. Obviously, the two objectives involve a tradeoff.

On the one hand, passenger volume depends on the distinctiveness and superiority of a particular cruise. The more distinctive and superior the cruise becomes, the more passengers it will attract. On the other hand, the operation costs are decided by superiority; the more superior the cruise, the higher the cost. Since a cruise ship is a tourist and leisure facility rather than traffic vehicle, its superiority is determined 
by its itinerary, ports of call, onboard facilities, and length of voyage. To increase the quality of the cruise, the operator must spend more money. The above model can simulate the interaction between the traded off objectives. By solving the model, the cruise itinerary scheme and its corresponding passenger volume under equilibrium can be obtained.

Equation 3 means that Port 1 is the home port. Equation 4 means that the cruise itinerary is a oneway loop. Equation 5 ensures that the home port is on the itinerary. Equation 6 limits the voyage time to 2-5 days, thus meeting the needs of northeast China's middle-income families. Equation 7 indicates that there should be two or more ports of call.

$L$ is the set of feasible itinerary schemes, and $I=X_{n}=\left(\begin{array}{ccc}x_{11} & \cdots & x_{1 n} \\ \vdots & \ddots & \vdots \\ x_{n 1} & \cdots & x_{n n}\end{array}\right) \in L$ is an itinerary scheme. Other variables are calculated as follows:

Voyage daily cost:

$$
Z=\left(C_{P}+C_{S}+T \cdot N_{C} \cdot C_{W}\right) / T
$$

$T=$ voyage time; $C_{P}=$ port-related costs; $C_{S}=$ sailing costs; $N_{C}=$ number of crew members; and $C_{W}=$ daily crew wage.

$$
\begin{aligned}
& T=T_{S}+T_{P} \\
& T s=\frac{\left(\sum_{i=1}^{n} \sum_{i=1}^{n} x_{i j} d_{i j}\right)}{(v \cdot 24)} \\
& T p=0.25 \cdot \sum_{i=1}^{n} \sum_{j=1}^{n} x_{i j}
\end{aligned}
$$

$T_{S}=$ sailing time; $T_{P}=$ in port time; $d_{i j}=$ sailing distance from port $i$ to port $j ; v=$ sailing speed.

Passenger volume:

$Q=\frac{\sum_{i=1}^{n} \sum_{j=1}^{n} U_{i j}}{U_{\max } \cdot Q_{i j}^{0} \cdot x_{i j}}$

$Q_{i j}^{0}=$ potential passenger volume between ports $i, j$;

$U_{i j}=\frac{\left(\sum_{j} x_{i j} \cdot P_{j}\right) \cdot N_{c}}{Q_{i j}^{0}}$ utility of itinerary $/$ to the passenger between ports $i, j$;

$U_{\max }=T_{d} \cdot\left(\sum_{i} P_{i}\right) \cdot S_{b}$, expected maximum utility; $P_{j}=$ attraction of port $j$, which can be evaluated according to preference for ports of call; $T_{d}=$ expected maximum voyage days; and $S_{b}=$ standard ratio between number of crew members and number of passengers on board.

Port-related costs: $C^{P}=\frac{\alpha \sum_{i=1}^{n} \sum_{j=1}^{n} x_{i j}+Q}{\Delta \cdot \gamma}$

Sailing costs: $C_{S}=T_{S} \cdot F C \cdot F C P \cdot T_{p} \cdot D C \cdot D C P$

$\alpha=$ port tariff; $\Delta=$ passenger boarding speed; and $y=$ boarding fare (charged by time). $F C=$ daily consumed heavy oil; $F C P=$ price of heavy oil; $D C=$ daily consumed light oil; and $D C P=$ price of light oil.

\subsection{Algorithm design and model solution}

The above model consists of a knapsack problem and a traveling salesman problem. Due to its large-scale computation, problem-solving speed would have been slow if a direct search algorithm were applied. Thus, for an actual application, heuristic algorithm is often a first choice [32-34]. In particular, generation algorithm is applied to solve bus lane network design. In their paper, it can be that the generation algorithm is an effective method to solve this kind of line optimization [34]. Thus, the model is solved by a modified genetic algorithm based on the matrix coding method. The calculation steps were as follows.

\section{a) Coding}

The cruise itinerary schemes were coded as an $n \cdot n$ binary matrix ( $n=$ number of available ports). The left hand side of Figure 5 shows the itinerary code when $n=7$. The right hand side shows the corresponding voyage itinerary scheme.

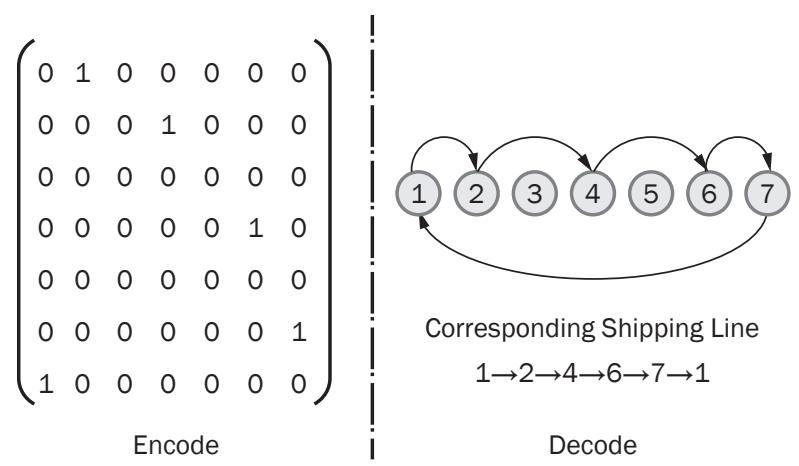

Figure 5 - Code and structure of the cruise line

Matrix coding can effectively solve the problem that general coding cannot judge individual legality. Moreover, matrix coding has multiple advantages. For example, it can judge the legality of the generated individuals both visually and intuitively, and it can easily calculate fitness value, generate diverse individuals, expand search space, and transform illegal individuals into legal ones [35-37]. According to the requirements of the feasible solution, coding must meet the following conditions: 1 ) the number of " 1 " $s$ in the matrix must be between 2 and 5; and 2) the " 1 "s must be included in the different rows and columns, not in the diagonal.

Legalization of illegal individuals must go through the following steps.

Step 1: Check the elements in the diagonal. If all of them are " 0 ", then go to the next step. Otherwise, replace " 1 " with " 0 ". 


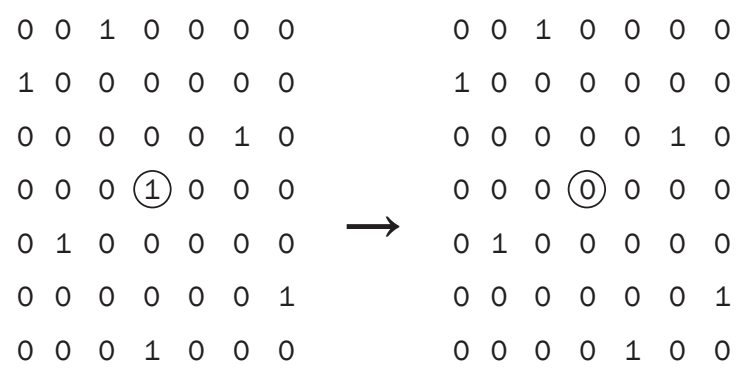

Figure 6 - step 1

Step 2: Check the elements in the first column and the first row. There must be one " 1 " in the first row and the first column, respectively. Otherwise, change one " 0 " that is not in the diagonal to " 1 ". Correspond to Equation 3.

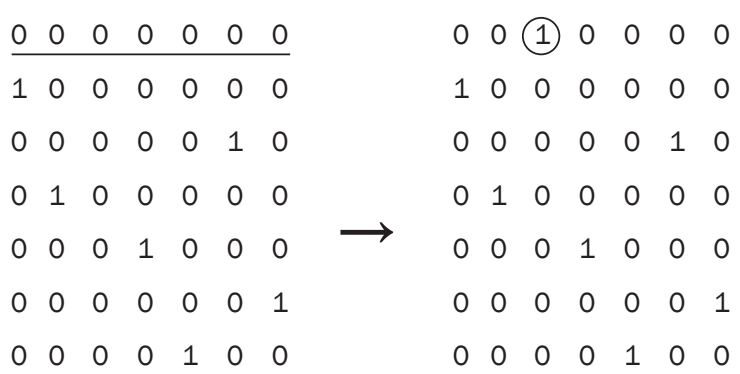

Figure 7 - step 2

Step 3: From row i, take the following sub-steps:

1) Check to see whether an element in the non-diagonal of row $i$ is " 1 " and other elements in the corresponding column are all "0". If "Yes", then keep " 1 " unchanged. Otherwise, change the " 1 "s referred to longer distance between two ports to "0"s. Correspond to Equation 4.
$\begin{array}{lllllll}0 & 0 & 1 & 0 & 0 & 0 & 0\end{array}$
$\begin{array}{lllllll}0 & 0 & 1 & 0 & 0 & 0 & 0\end{array}$
$\begin{array}{lllllll}1 & 0 & 0 & 0 & 0 & 0 & 0\end{array}$
$\begin{array}{lllllll}1 & 0 & 0 & 0 & 0 & 0 & 0\end{array}$
$\begin{array}{lllllll}0 & 0 & 0 & 0 & 0 & 1 & 0\end{array}$
$\begin{array}{lllllll}0 & 0 & 0 & 0 & 0 & 1 & 0\end{array}$
(0) 1000000
$\begin{array}{lllllll}0 & 1 & 0 & 0 & 0 & 0 & 0\end{array}$
$\begin{array}{lllllll}0 & 0 & 0 & 1 & 0 & 0 & 0\end{array}$
$\begin{array}{lllllll}0 & 0 & 0 & 1 & 0 & 0 & 0\end{array}$
$\begin{array}{lllllll}0 & 0 & 0 & 0 & 0 & 0 & 1\end{array}$
$\begin{array}{lllllll}0 & 0 & 0 & 0 & 0 & 0 & 1\end{array}$
(0) $1 \quad 0 \quad 0 \quad 0000$
(0) $0 \begin{array}{lllllll}0 & 0 & 0 & 0 & 0 & 0\end{array}$

Figure 8 - step 3-1

2) If there is more than one " 1 " in the row, then change "1"s referred to shorter distance between two ports in the row and the corresponding column to "0"s. Correspond to Equation 4.

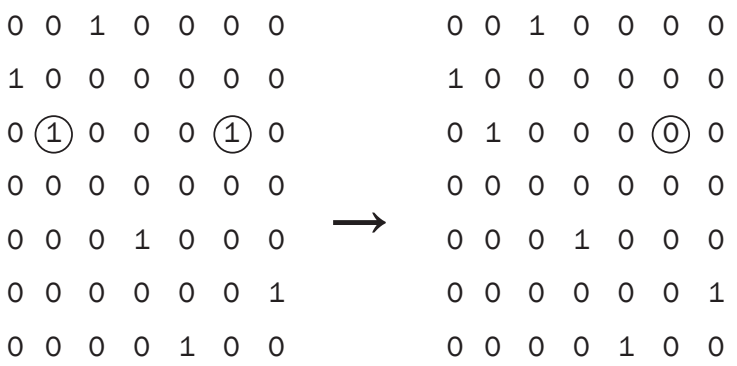

Figure 9 - step 3-2

3) If all of the elements in row $i$ are "0"s, then change "O" referred to shorter distance between two ports on the non-diagonal to " 1 ".
$\begin{array}{lllllll}0 & 0 & 1 & 0 & 0 & 0 & 0\end{array}$
$\begin{array}{lllllll}0 & 0 & 1 & 0 & 0 & 0 & 0\end{array}$
$\begin{array}{lllllll}1 & 0 & 0 & 0 & 0 & 0 & 0\end{array}$
$\begin{array}{lllllll}1 & 0 & 0 & 0 & 0 & 0 & 0\end{array}$
$\begin{array}{lllllll}0 & 1 & 0 & 0 & 0 & 0 & 0\end{array}$
$\begin{array}{lllllll}0 & 1 & 0 & 0 & 0 & 0 & 0\end{array}$
$\begin{array}{lllllll}0 & 0 & 0 & 0 & 0 & 1 & 0\end{array}$
$\begin{array}{lllllll}0 & 0 & 0 & 0 & 0 & 1 & 0\end{array}$
\begin{tabular}{lllllll}
0 & 0 & 0 & 0 & 0 & 0 & 0 \\
\hline 0 & 0 & 0 & 0 & 0 & 0 & 1
\end{tabular}
$\longrightarrow \quad 00$ (1) 00000
$\begin{array}{lllllll}0 & 0 & 0 & 0 & 0 & 0 & 1\end{array}$
$\begin{array}{lllllll}0 & 0 & 0 & 0 & 1 & 0 & 0\end{array}$
$\begin{array}{lllllll}0 & 0 & 0 & 0 & 1 & 0 & 0\end{array}$

Figure 10 - step 3-3

4) If " 1 " in row $i$ has a symmetry element, exchange that row with any row in the matrix until no symmetry elements are left. Correspond to Equation 5.
$\begin{array}{lllllll}0 & 0 & 0 & 1 & 0 & 0 & 0\end{array}$
$\begin{array}{lllllll}0 & 0 & 0 & 1 & 0 & 0 & 0\end{array}$

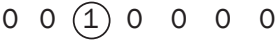
0 (1) $0 \begin{array}{lllll}0 & 0 & 0 & 0 & 0\end{array}$
\begin{tabular}{lllllll}
1 & 0 & 0 & 0 & 0 & 0 & 0 \\
\hline 0 & 1 & 0 & 0 & 0 & 0 & 0
\end{tabular}
$0 \begin{array}{lllllll}0 & 0 & 0 & 0 & 0 & 1 & 0\end{array}$
$\begin{array}{lllllll}0 & 0 & 0 & 0 & 0 & 1 & 0\end{array}$
$\begin{array}{lllllll}1 & 0 & 0 & 0 & 0 & 0 & 0\end{array}$
\begin{tabular}{lllllll}
0 & 0 & 1 & 0 & 0 & 0 & 0 \\
\hline 0 & 0 & 0 & 0 & 0 & 0 & 1
\end{tabular}
$\begin{array}{lllllll}0 & 0 & 0 & 0 & 0 & 0 & 1\end{array}$
$\begin{array}{lllllll}0 & 0 & 0 & 0 & 1 & 0 & 0\end{array}$

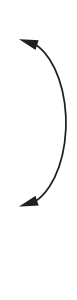

Figure 11 - step 3-4

Step 4: The number of "1"s in the matrix must be between 2 and 5. Correspond to Equation 6.
$\begin{array}{lllllll}0 & 0 & 0 & \text { (1) } & 0 & 0 & 0\end{array}$
$\begin{array}{lllllll}0 & 0 & 0 & \text { (1) } & 0 & 0 & 0\end{array}$
$0 \begin{array}{lllllll}0 & 0 & 0 & 0 & 0 & 0 & \text { (1) }\end{array}$
$\begin{array}{lllllll}0 & 0 & 0 & 0 & 0 & 0 & 0\end{array}$
(1) $0 \quad 0 \quad 0 \quad 000$
(1) $0 \begin{array}{lllll}0 & 0 & 0 & 0 & 0\end{array}$
$\begin{array}{lllllll}0 & 0 & 0 & 0 & 0 & 1 & 0\end{array}$
$\begin{array}{lllllll}0 & 0 & 0 & 0 & 0 & \text { (1) } & 0\end{array}$
$\begin{array}{lllllll}0 & 0 & 0 & 0 & 0 & 0\end{array}$

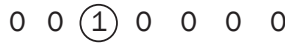
$\begin{array}{lllllllllllll}0 & 0 & 0 & 0 & 1 & 0 & 0\end{array}$
$\begin{array}{lllllll}0 & 0 & 0 & 0 & (1) & 0 & 0\end{array}$
$\begin{array}{lllllll}0 & 0 & 0 & 0 & 0 & 0 & 0\end{array}$
$\begin{array}{lllllll}0 & 0 & 0 & 0 & 0 & 0 & 0\end{array}$

Figure 12 - step 4 
Sub-steps 1-4 will not stop until all "1"s in the matrix are in different rows and different columns.

\section{b) Construction of the fitness function}

Change the dual objectives into a single objective with $w$, which is daily profit per passenger, to make the fitness function:

$$
\operatorname{Fit}(f(x))=w Q(I)-f(Q, I)
$$

\section{c) Selection operation}

The roulette-wheel selecting method is used to select individuals as follows.

Suppose the number of individuals is $N$, and set $\sum_{i=1}^{n} f_{i}$ is the sum of the fitness value of the entire population. Here, $f_{i}$ is the fitness value of individual $i$. The ability of an individual to generate children equals the proportion of their fitness value to that of the whole population, which is as follows:

$$
\frac{f_{i}}{\sum_{i=1}^{n} f_{i}}
$$

This selection method can ensure that the stronger individuals are always strong and the weaker ones are always weak when the fitness values of one or more chromosomes are greater than those of other individuals. This is good for convergence.

\section{d) Crossover operation}

Randomly select any column or row of two parent individuals and exchange them to generate new individuals for the next generation.

\section{e) Mutation operation}

Select any two elements (or two columns/rows) from the parent individuals with probability $\mathrm{Pm}$, and swap them.

\section{f) Update operation}

If the fitness value of a new individual is larger than that of the original individual, then replace the original individual with the new one. Otherwise, continue to use the original individual to perform the crossover and mutation operations until the best individual is found.

\section{g) Termination of the algorithm}

Do not terminate the calculation until the smallest fitness value does not change markedly after $M$ generations of calculation. The $M$ may be properly set as $M=N$.

\section{NUMERICAL EXAMPLE}

\subsection{Input data}

1) The DWG of the ship is 50,000 tons and its passenger capacity is 3,000 persons;

2) The cruise ship speed is 20 ;

3) The maximum number of crew members on board is 500 ;

4) The average crew-member wage is 350 Yuan/day;

5) Passenger boarding speed is 500 persons per hour;

6) The tariff for passenger boarding is 400 Yuan/hour;

7) Daily fuel consumption and cost are as follows: 130 tons/day (at 5,600 Yuan/ton) of heavy oil, 10 tons/day (at 8,500 Yuan/ton) of light oil;

8) The disbursement at each port of call is 170,000 Yuan/time, which is the charging benchmark of the Xiamen International Cruise Terminal;

9) The daily profit per passenger;

10) The potential passenger OD matrix is shown in Table 2;

11) Sailing distances between ports are shown in Table 3.

\subsection{Analysis of outputs}

The algorithm program was computed, the mutation rate $(\mathrm{Pm})$ was set at 0.6 , the size of the initial population was set at 20 , and the iteration times were set at 1,000. After 385 calculations, the algorithm tended to converge. Figure 13 shows the convergence situation.

\begin{tabular}{|c|c|c|c|c|c|c|c|}
\hline${ }^{j}$ & $\begin{array}{c}1 \\
\text { Dalian }\end{array}$ & $\begin{array}{c}2 \\
\text { Tianjin }\end{array}$ & $\begin{array}{c}3 \\
\text { Qinhuangdao }\end{array}$ & $\begin{array}{c}4 \\
\text { Yantai }\end{array}$ & $\begin{array}{c}5 \\
\text { Weihai }\end{array}$ & $\begin{array}{c}6 \\
\text { Qingdao }\end{array}$ & $\begin{array}{c}7 \\
\text { Shanghai }\end{array}$ \\
\hline 1 & 0 & 11.77 & 5.53 & 9.16 & 7.57 & 38.2 & 60.79 \\
\hline 2 & 1.33 & 0 & 1.56 & 2.54 & 4.14 & 10.51 & 56.65 \\
\hline 3 & 0.06 & 0.14 & 0 & 0.23 & 0.11 & 0.87 & 2.79 \\
\hline 4 & 0.13 & 0.22 & 0.07 & 0 & 0.04 & 3 & 9.11 \\
\hline 5 & 0.14 & 0.37 & 0.05 & 0.13 & 0 & 0.53 & 2.96 \\
\hline 6 & 2.06 & 9.16 & 0.66 & 1.81 & 1.33 & 0 & 111.27 \\
\hline 7 & 47.61 & 67.09 & 16.91 & 32.51 & 14.24 & 97.65 & 0 \\
\hline
\end{tabular}

Table 2 - Forecasted potential cruise tourists between ports in 2015 ( $T_{i j}$ : 1,000 persons) 
Table 3 - Distance between ports (in miles)

\begin{tabular}{||l|c|c|c|c|c|c|c||}
\hline \hline \multicolumn{1}{|c|}{ Ports } & Dalian & Tianjin & Qinhuangdao & Yantai & Weihai & Qingdao & Shanghai \\
\hline \hline Dalian & 0 & 213 & 170 & 89 & 93 & 279 & 556 \\
\hline Tianjin & 213 & 0 & 115 & 189 & 223 & 422 & 695 \\
\hline Qinhuangdao & 170 & 115 & 0 & 173 & 197 & 377 & 657 \\
\hline Yantai & 89 & 189 & 173 & 0 & 47 & 238 & 519 \\
\hline Weihai & 93 & 223 & 197 & 47 & 0 & 200 & 480 \\
\hline Qingdao & 279 & 422 & 377 & 238 & 200 & 0 & 408 \\
\hline Shanghai & 556 & 695 & 657 & 519 & 480 & 408 & 0 \\
\hline
\end{tabular}

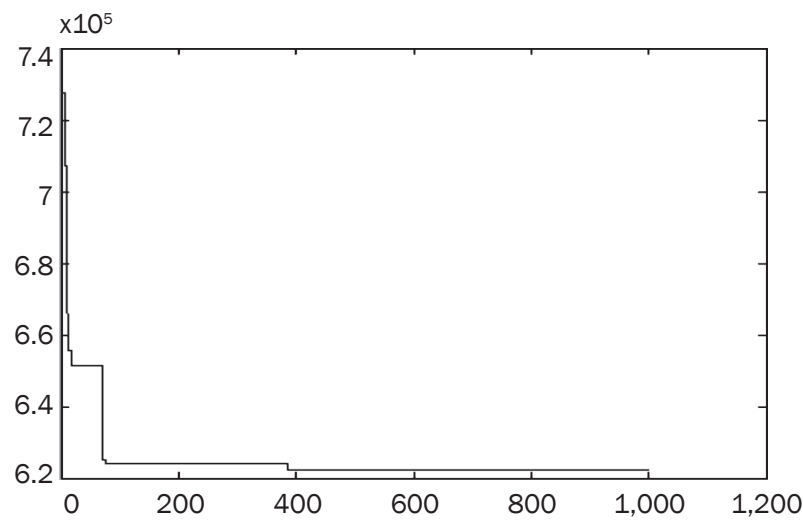

Figure 13 - Convergence situation

The genetic algorithm has been executed repeatedly ten times and the results are shown in Figure 14 The relative deviation of their itinerary scheme versus the optimal itinerary scheme is about $7.92 \%$.

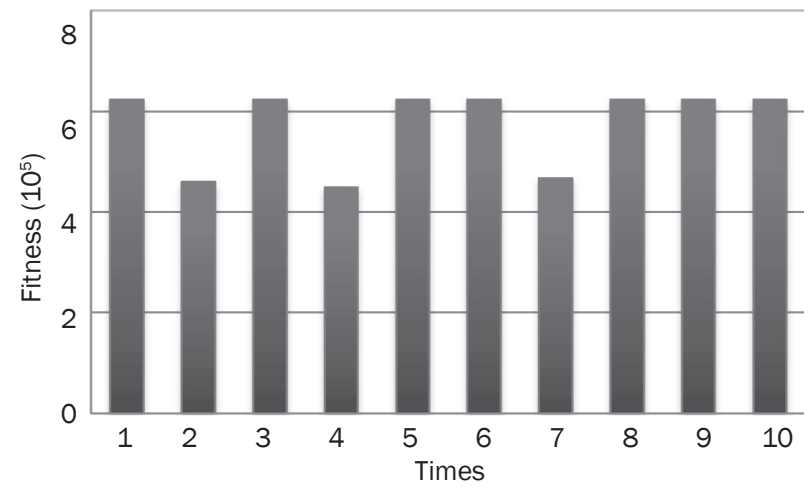

Figure 14 - The computational results of genetic algorithms

To test the accuracy of the result by genetic algorithm, the branch-and-bound method has been used to solve the model. The obtained solution is the same as the solution we got by the genetic algorithm. However, facing the problem of larger scale in the future, genetic algorithm is proposed as the most suitable tool in the paper, because branch-and-bound method may not obtain the solution in a limited time.

The output cruise itinerary scheme is shown in Figure 15 as Dalian-Qingdao-Shanghai-Tianjin-
Weihai- Dalian. The travel time of the itinerary is 4.79 days, daily voyage cost is 0.84 million RMB, which is not the cheapest possible; however, it reaches equilibrium between cost and market scale. The annual market demand is 200,840 trips.

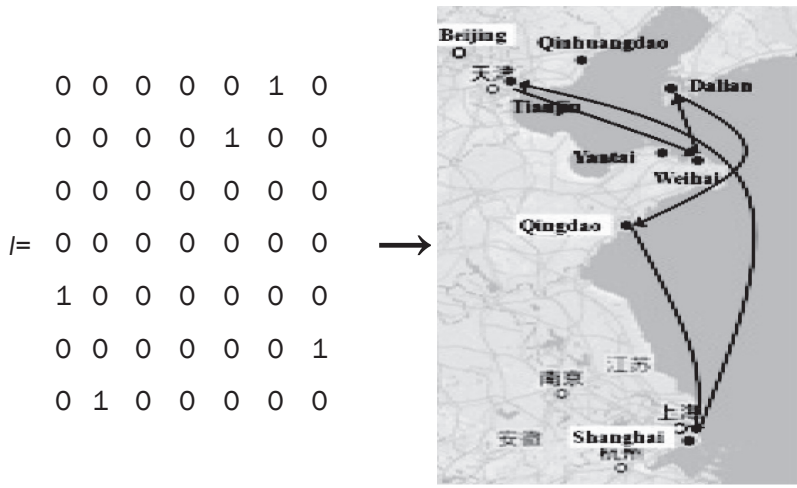

Figure 15 - Optimized cruise itinerary scheme

Among the seven given ports, five of them are the ports of call of the cruise itinerary. They are Shanghai port, Qingdao port, Dalian port, Tianjin port, and Weihai port. Four of them (Shanghai port, Qingdao port, Dalian port, Tianjin port) have large amount of potential cruisers (Top four), and the cities of the four ports hold leading positions in terms of infrastructure, tourist resources, and amenities. Thus calling at them cannot only make the cruise tourists enjoy the journey more but also help to collect more passengers.

The left two ports (Yantai and Qinghuangdao) are not the ports of call. Among the seven ports, their potential tourists rank $5^{\text {th }}$ and $7^{\text {th }}$ respectively. It is obviously that there is not enough cruise traffic for being called. Moreover, as Figure 4 shows, the cities of Yantai and Qinghuangdao are not the preferred spot sites of the tourists. From Figure 15, it can further be seen that their locations are not good enough, and calling them may induce additional voyaging time.

Although the potential cruise tourists rank Weihai city as $6^{\text {th }}$ and its reputation and attractiveness are not as good as the one of Qingdao, Tianjin and Shanghai, it is rich with tourist attractions and can meet tourist demand as a new travel destination. This can also be verified by the tourists' preference shown in Figure 4. 
As the result, Weihai port is a port of call although its cruise traffic is not so large.

The 4.79 days of travel time of the optimized itinerary meet the expectations of cruises of the middle-income families that last 2-5 days. The operators can set the duration of one voyage as 5 days, and then one ship can run 73 voyages annually if the impact of the seasonality and weather are not considered. It means that a ship with a capacity of 3,000 passengers can serve 219,000 tourists in one year. The total number of potential cruise tourists at the five port cities is 616,230; thus an operator can use three ships to serve them with Shanghai, Qingdao and Dalian as home ports.

\section{CONCLUSIONS}

This study examined cruise-tourist-related demand attributes of the middle-income families in northeast China using a questionnaire, and found a large demand for coastal cruises. Since vacation of Chinese middle-income families is relatively short and for international cruise applying for visas costs time and money, Chinese middle-income families prefer low prices and short voyages. Furthermore, for the domestic short-voyage cruise, middle-income tourists prefer the cities of ports of call to have some natural landscapes and some historic attractions, and they prefer midpriced onboard accommodations and entertainment facilities.

To develop coastal cruise tourism in a rational manner, the cruise itineraries are important. For converting as many potential tourists to real cruisers, we developed a model to design a coastal cruise line for China's middle-income families with the aim to offer tools for the operator's marketing. The model links passenger volume to operating cost and simulates the interaction and process of the equilibrium between volume and cost via dual-objective functions. This model can calculate both cruise itineraries and numbers of passengers. With the case study, the power of the model has been proven because the output cruise itinerary scheme is reasonable and almost all of the potential demand is converted into real cruisers.

Cruise tourism involves many aspects and factors, some of which are not addressed in this paper. For example, only fuel consumption costs and ships' port dues are considered, whereas procurement and maintenance costs are not. Moreover, for convenience of calculation, port tariffs were considered as being homogeneous. In reality, however, port tariffs may vary from port to port. In the future, these issues will be analysed thoroughly for additional results. It is easy to figure out that the data on the potential cruise tourists in China are difficult to obtain, so the survey only covered the northeast of China. With the construction of more Chinese cruise terminals, further research should refer to more ports and more people. Besides, the model proposed in the paper is mainly focused on the cost of cruise line. In fact, tourist satisfaction of the cruise trip could affect the choice behaviours of tourists. Therefore, the effect of the human behaviour on the optimization of cruise line will be studied in the future.

\section{ACKNOWLEDGEMENT}

The authors would like to acknowledge the research support received from the National Natural Science Foundation of China (Grant No. 71431001).

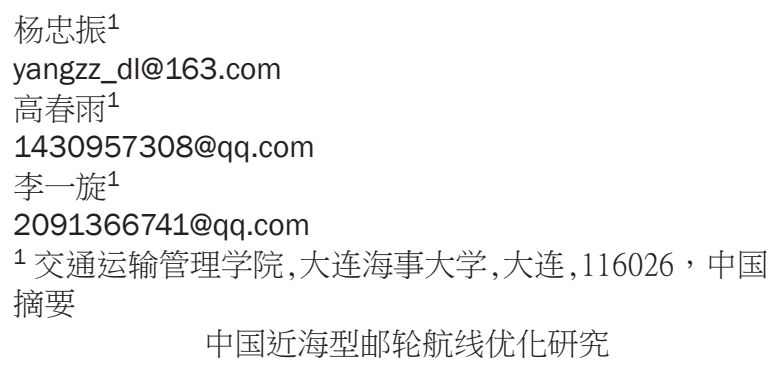

本文对中国的邮轮市场的现状进行分析并提出了建立近海 型邮轮航线模型的构想。通过问卷调查, 对中等收入家庭 的期望航行天数、期望挂靠港等需求进行了解。以未来中 等收入家庭 (无论是否经历过邮轮旅游) 对邮轮旅行的需 求数据为基础, 考虑到邮轮航线及行程安排, 构建了以最 大化乘客数量和最小化运营成本为目标的邮轮航线设计模 型。通过矩阵编码的遗传算法对模型进行求解。实例研究 发现, 行程为 4.79 天时模型取得均衡解, 此时, 该邮轮 航线年需求量为 20.084 万人次, 而日均航次成本为 84.3 万元。

\section{关键词}

邮轮旅游；矩阵编码；近海型邮轮

\section{REFERENCES}

[1] Larsen S, Wolff K, Marnburg E, Torvald Ø. Belly full, purse closed: Cruise line passengers' expenditures. Tourism Management Perspectives. 2013 Apr;6:142148.

[2] Dowling R, editor. Cruise ship tourism. CABI; 2006.

[3] The research group of China cruise development report. 2008-2009 China Cruise Industry Development Report [in Chinese]. Beijing: China Cruise \& Yacht Industry Association, et al; 2009.

[4] The research group of China cruise development report. 2009-2010 China Cruise Industry Development Report [in Chinese]. Shanghai: China Cruise \& Yacht Industry Association, et al; 2010.

[5] China Cruise \& Yacht Industry Association, et al. 20102011 China Cruise Industry Development Report [in Chinese]. Shanghai: China Cruise \& Yacht Industry Association, et al; 2011.

[6] China Cruise \& Yacht Industry Association. 2011-2012 Report on the development of Chinese cruise industry [in Chinese]. Shanghai: Pujiang Education press; 2012 
[7] Ministry of Transport of the People's Republic of China. Transport development in the 12th 'Five-Year-Plan' period [in Chinese]. Beijing: Ministry of Transport of the People's Republic of China; 2011.

[8] Heung VCS, Wong MY, Hailin Q. Airport-restaurant service quality in Hong Kong: An application of SERVQUAL. The Cornell Hotel and Restaurant Administration Quarterly, 2000;41(3):86-96.

[9] Qu H, Ping EWY. A service performance model of Hong Kong cruise travelers' motivation factors and satisfaction. Tourism Management. 1999;20(2):237-244.

[10] Teye VB, Leclerc D. Product and service delivery satisfaction among North American cruise passengers. Tourism Management. 1998;19(2):153-160.

[11] Duman T, Mattila AS. The role of affective factors on perceived cruise vacation value. Tourism Management. 2005;26(3):311-323.

[12] Klein RA. Cruise ship squeeze: The new pirates of the seven seas. New Society Publishers; 2005.

[13] Johnson D. Environmentally sustainable cruise tourism: a reality check. Marine Policy. 2002;26(4):261270.

[14] Hwang J, Han H. Examining strategies for maximizing and utilizing brand prestige in the luxury cruise industry. Tourism Management. 2014;40(2):244-259.

[15] Henthorne TL. An analysis of expenditures by cruise ship passengers in Jamaica. Journal of Travel Research. 2000;38(3):246-250.

[16] Lee S, Ramdeen C. Cruise ship itineraries and occupancy rates. Tourism Management. 2013;34:236-237.

[17] Dickinson B, Vladimir A. Selling the sea: An Inside Look at the Cruise Industry, 2nd edition. Wiley; 2008.

[18] Hersh M, Ladany SP. Optimal seat allocation for flights with one intermediate stop. Computers \& Operations Research. 1978;5(1):31-37.

[19] Leong TY, Ladany SP. Optimal cruise itinerary design development. International Journal of Services Technology and Management. 2001;2(1):130-141.

[20] Rodrigue JP, Notteboom T. The geography of cruises: Itineraries, not destinations. Applied Geography. 2013;38:31-42.

[21] Véronneau S, Roy J. Global service supply chains: An empirical study of current practices and challenges of a cruise line corporation. Tourism Management. 2009;30(1):128-139.

[22] Luo PC, Zhang YY, She SF. Study of SWOT Analysis and Countermeasures on Cruise Tourism in the West Coast of the Straits Economic Zone [in Chinese]. Journal of Chongqing Normal University(Natural Science). 2011 Jan;1(28):82-87.

[23] Zhang FF, Fang BS. Prospect analysis of Qingdao cruise tourism [in Chinese]. China Water Transport (Theory Edition). 2006 Jun;6(4):24-26.
[24] Sun RH, Ye XL. Study on the development of cruise tourism market in Shanghai [in Chinese]. Inquiry into Economic Issues. 2007;3:165-169.

[25] Wang GL, Lou JJ. Marketing location of international cruise liner companies and its inspiration to Shanghai [in Chinese]. Journal of Henan Business College. 2008;4(21):59-64.

[26] Yao BZ, Hu P, Lu XH, Gao JJ, Zhang MH. Transit network design based on travel time reliability. Transportation Research Part C. 2014;43:233-248.

[27] Yao BZ, Hu P, Zhang MH, Tian XM. Improved Ant Colony Optimization for Seafood Product Delivery Routing Problem. Promet - Traffic \& Transportation. 2014;26(1):1-10.

[28] Yu B, Peng ZX, Wang KM, Kong L, Cui Y, Yao BZ. Optimization method for line planning and operation strategy of waterbus: the case of Zhoushan city. Operational Research. 2015;15(1):25-49.

[29] Andriotis K, Agiomirgianakis G. Cruise visitors' experience in a Mediterranean port of call. International Journal of Tourism Research. 2010;12(4):390-404.

[30] Gibson P, Bentley M. A Study of Impacts-Cruise Tourism and the South West of England. Journal of Travel \& Tourism Marketing. 2007;20(3-4):63-77.

[31] Yao BZ, Yu B, Gao JJ, Zhang MH. An improved particle swarm optimization for carton heterogeneous vehicle routing problem with a collection depot. Annals of Operations Research. 2016;242(2):303-320.

[32] Zhang YD, Wang SH, Phillips P, Ji GL. Binary PSO with Mutation Operator for Feature Selection using Decision Tree applied to Spam Detection. Knowledge-Based Systems. 2014;64:22-31.

[33] Zhang YD, Wu LN. Crop Classification by forward neural network with adaptive chaotic particle swarm optimization. Sensors. 2011;11(5):4721-4743.

[34] Yu B, Kong L, Sun Y, Yao BZ, Gao ZY. A bi-level programming for bus lane network design. Transportation Research Part C. 2015;55:310-327.

[35] Yao BZ, Chen C, Cao QD, Jin L, Zhang MH, Zhu HB, Yu B. Short-term traffic speed prediction for an urban corridor. Computer-Aided Civil And Infrastructure Engineering, accept.2016. doi: 10.1111/mice.12221.

[36] Yu B, Zhu HB, Cai WJ, Ma N, Yao BZ. Two-phase Optimization Approach to Transit Hub Location--the Case of Dalian. Journal of Transport Geography. 2013;33:6271.

[37] Wang H, Li HP, Liu JF. Modified genetic algorithm for TSP based on matrix coding. Journal of Leshan Teachers College. 2008;12:47-50 